\title{
Studi Fenomenologi : Pengalaman Interaksi Sosial Lansia Dengan Sesama Lansia Dan Pengasuh Di Panti Sosial Tresna Werdha "Sabai Nan Aluih" Sicincin Kabupaten Padang Pariaman Tahun 2012
}

\author{
Debby Sinthania $^{a}$, Emil Huriania ${ }^{a}$, Gusti Sumarsih ${ }^{a}$ \\ aprogram Studi Ilmu Keperawatan Fakultas Kedokteran Universitas Andalas
}

\begin{abstract}
Decline in health and physical abilities occurs in the elderly is accompanied by the condition of loneliness and isolation as in a nursing Tresna Wedha affect social interaction in quantity and quality of older adults. This study aimed to explore the experience of social interaction with fellow seniors and caregivers in the Elderly Social Institution Sabai Nan Aluih, Sicincin Pariaman District 2012. This type of research is a qualitative phenomenological approach. The number of informants as many as 6 people, the selection of informants in a purposive sampling with specific criteria, namely the 24-hour caregiver living in nursing. Data collection techniques in depth interview and documentation study, and observation. Data collection tool is the interview guide and a tape recorder (recorder). Data processing is done by recording, making transcripts, extracts, and thematic analysis of the five variables, namely the study of cooperation, communication, conflict, caregiver services provided, and action / caregivers how to work both the favorable and less fun. The study found five themes namely: Cooperation maintain the cleanliness of the guest house and helping a friend who is ill, elderly Efforts to establish communication with peers, and cause conflict among the elderly, caregiver services rendered type, attitude and behavior of caregivers in the interaction. Suggested that more intensive and proactive caregivers provide social assistance, more flexible, and actively participate in every activity in nursing. Suggested to the leadership of nursing training on elderly social worker, the researchers recommended further research in quantitative social interaction according to the themes that have been identified.
\end{abstract}

\section{Keywords: Social Interaction, Elderly, Caregivers}

\begin{abstract}
Abstrak : Penurunan derajat kesehatan dan kemampuan fisik yang terjadi pada lansia disertai dengan kondisi kesepian dan terisolasi karena berada di Panti Tresna Wedha mempengaruhi interaksi sosial lansia secara kuantitas maupun kualitas. Penelitian ini bertujuan untuk mengeksplorasi pengalaman interaksi sosial sesama lansia dan dengan pengasuh di Panti Sosial Tresna Werdha Sabai Nan Aluih, Sicincin Kabupaten Padang Pariaman Tahun 2012. Jenis penelitian adalah kualitatif dengan pendekatan fenomenologi. Jumlah informan sebanyak 6 orang, pemilihan informan secara purposive sampling dengan kriteria spesifik yaitu dengan pengasuh yang tinggal 24 jam di panti. Teknik pengumpulan data dengan wawancara mendalam dan studi dokumentasi, dan observasi. Alat pengumpul data adalah pedoman wawancara dan alat perekam (recorder). Pengolahan data dilakukan dengan mencatat, membuat transkrip, intisari, dan analisis tematik dari 5 variabel penelitian yaitu kerjasama, komunikasi, konflik, pelayanan yang diberikan pengasuh, dan tindakan/cara kerja pengasuh baik itu yang menyenangkan maupun yang kurang menyenangkan. Hasil penelitian didapatkan 5 tema yakni : Kerjasama menjaga kebersihan wisma dan menolong teman yang sakit, Upaya lansia menjalin komunikasi dengan sesama teman, Konflik sesama lansia dan penyebabnya, Jenis Pelayanan yang diberikan pengasuh, Sikap dan perilaku pengasuh dalam interaksi. Disarankan agar pengasuh lebih intensif dan proaktif memberikan bimbingan sosial, lebih luwes, dan berpartisipasi aktif pada setiap kegiatan di panti. Pimpinan panti disarankan sebaiknya perlu dilakukan pelatihan tentang pekerja sosial lanjut usia, kepada peneliti selanjutnya disarankan untuk meneliti interaksi sosial secara kuantitatif sesuai tema yang sudah terindentifikasi.
\end{abstract}

Kata Kunci : Interaksi sosial, Lansia, Pengasuh 
Manusia tidak lepas dari proses alamiah yang salah satunya adalah proses penuaan. Proses penuaan adalah suatu proses menghilangnya secara perlahanlahan kemampuan memperbaiki diri atau menggantikan dan mempertahankan fungsi normalnya sehingga tidak dapat bertahan hidup terhadap infeksi dan memperbaiki kerusakan yang diderita (Nugroho, 2010).

Pesatnya perkembangan ilmu pengetahuan di berbagai bidang termasuk ilmu pengetahuan dalam bidang kesehatan, mengakibatkan peningkatan umur harapan hidup manusia yang membawa dampak pada peningkatan jumlah lansia. Penduduk lanjut usia (lansia) adalah bagian dari penduduk secara keseluruhan. Seperti halnya kelompok penduduk lainnya, kelompok lansia juga tetap ingin mandiri, berkarya, dan bersosialisasi ditengah masyarakat. Mereka tidak ingin menjadi beban dan tergantung pada orang lain, termasuk keluarganya. Selain itu, mereka juga selalu ingin dapat bergaul, dihargai dan bukan disisihkan di lingkungannya (Departemen Sosial [Depsos] ,2007).

Menurut data yang dikeluarkan oleh Perserikatan Bangsa-Bangsa (PBB), melalui lembaga kependudukan dunia United Nations Population Fund (UNFPA), jumlah lansia, pada tahun 2009 telah mencapai jumlah 737 juta jiwa. Organisasi Kesehatan Dunia mengatakan bahwa penduduk lansia di Indonesia pada tahun 2010 sudah 9,77 persen dari total penduduk dan tahun 2020 mendatang sudah mencapai angka $11,34 \%$ atau tercatat 28,8 juta orang sehingga menyebabkan jumlah penduduk lansia terbesar di dunia (Badan Pusat Statistik [BPS], 2007). Suatu wilayah disebut berstruktur tua jika persentase lanjut usianya lebih dari 7 persen. Dari seluruh provinsi di Indonesia, ada 11 provinsi yang penduduk lansianya sudah lebih dari 7 persen $(8,97 \%)$ , salah satunya yaitu Sumatera Barat (BPS Survei Sosial Ekonomi Nasional [Susenas], 2007). Menurut data BPS Sumbar (2011) jumlah penduduk di Sumatera Barat 4.956.274 orang dan dari jumlah tersebut
393.862 orang adalah penduduk lansia $(7,9 \%)$.

Meningkatnya jumlah penduduk lanjut usia tersebut berakibat semakin besarnya beban yang harus ditanggung oleh keluarga, masyarakat dan pemerintah dalam menyediakan pelayanan dan fasilitas lainnya bagi kesejahteraan lanjut usia. Kehidupan lanjut usia senantiasa membutuhkan komunikasi dan interaksi dengan orang lain. Interaksi sosial berpengaruh terhadap kehidupan kejiwaan lanjut usia. Kejiwaan yang sehat apabila hubungan dengan sesama tercipta dan berjalan dengan baik. Keadaan kejiwaan yang sehat dapat terpenuhi melalui hubungan yang memuaskan dengan sesama (Sarwono, 2002).

Sikap sosial pada lansia yang tidak menyenangkan, terlihat dari cara memperlakukan dan menganggap lansia tidak mampu serta tidak berdaya melakukan aktivitas sehari- hari. Tidak heran jika lansia mengembangkan konsep diri yang tidak menyenangkan terhadap dirinya. Perlakuan yang tidak menyenangkan, lanjut usia cenderung menarik diri dari partisipasi sosial (Hurlock, 2003).

Interaksi sosial adalah hubungan timbal balik yang saling mempengaruhi antara individu, kelompok sosial, dan masyarakat. Interaksi adalah proses dimana orang-orang berkomunikasi dan saling mempengaruhi dalam pikiran dan tindakan. Menurunnya derajat kesehatan dan kemampuan fisik akan mengakibatkan lansia secara perlahan menarik diri dari hubungan dengan masyarakat sekitar. Hal ini dapat menyebabkan interaksi sosial menurun (Hardywinoto \& Setiabudi, 2005).

Dalam kehidupan di panti diharapkan terjadi hubungan sosial yang harmonis antara lansia dengan sesama teman, antara lansia dengan pengasuh. Di antara lansia hendaknya tercipta ikatan kekeluargaan yang lebih luas. Rasa kekeluargaan dan rasa kebersamaan di antara para lansia dibina oleh pengasuh. Komunikasi merupakan alat untuk menjalin hubungan antara sesama mereka. Dengan 
berkomunikasi lansia merasa lebih akrab dan saling mengunjungi ke wisma masingmasing. Dengan demikian kesedihan dan beban pikiran mereka bisa berkurang (Devito, 2005).

Fenomena interaksi sosial yang terjadi dilapangan tidak dapat dipungkiri jika lanjut usia yang ada di panti tersebut kurang dapat melakukan interkasi sosial dengan orang-orang yang ada di panti tersebut baik sesama lanjut usia maupun para pengasuh. Sebagai contoh berdasarkan informasi yang didapat dari pengurus PSTW bahwa di mana rata-rata para lanjut usia yang tinggal di panti werdha sebagian besar mengalami kesulitan beradaptasi, terhambatnya dalam melakukan komunikasi yang baik terhadap penghuni lainnya, dan tidak dapat mengikuti dengan baik keterampilan serta kurang mampu berpatisipasi dalam kegiatan- kegiatan yang diadakan oleh panti werdha.

Kualitas dan intensitas interaksi sosial lansia dengan teman dan pengasuh, akan memberikan informasi dan kontribusi yang berharga bagi Panti Sosial Tresna Werdha "Sabai Nan Aluih" Sicincin untuk mencari suatu bentuk atau pola pengasuhan yang baik terhadap lansia di panti. Dengan interaksi yang baik, para lansia tidak merasa asing bergaul sesama lansia dan dengan pengasuh, sehingga lansia betah tinggal di panti dan merasa seperti di rumah sendiri (Gumay, 2011).

Studi awal yang penulis lakukan pada tanggal 29 September 2011 dengan mewawancarai 10 orang lansia didapatkan data bahwa 5 orang lansia mengatakan bahwa di antara mereka sering terjadi konflik dan pertengkaran, 6 orang mengatakan tidak pernah berkomunikasi dan berkunjung ke wisma tempat teman lain, 4 orang mengatakan bahwa pengasuh kurang maksimal memberikan pelayanan dan hanya tahu nama pengasuh saja.

\section{METODE}

Jenis penelitian adalah penelitian kualitatif dengan pendekatan fenomonologi untuk mengeksplorasi arti dan makna interaksi sosial lansia antara lansia dengan sesama lansia dan pengasuh di Panti Sosial Tresna Werdha "Sabai Nan Aluih" Sicincin Kabupaten Padang Pariaman Tahun 2012. Fokus penelitian fenomenologi adalah penemuan fakta suatu fenomena dan berusaha memahami tingkah laku manusia berdasarkan perspektif informan (Speziale \& Carpenter, 2007)

Populasi dalam penelitian ini adalah seluruh lansia yang tinggal di panti yang berjumlah 110 orang. Jumlah informan yang direkomendasikan oleh Rieman (1986) dikutip dari Creswell (2002) yaitu 3-10 orang partisipan, bila informasi sudah tercapai, maka pengambilan data dihentikan. Informan dalam penelitian ini berjumlah 6 orang. Pemilihan informan berdasarkan prinsip kesesuaian (approprieteness) dan kecukupan (adequacy). Jumlah informan tidak terlalu banyak karena penelitian ini bersifat kualitatif dan untuk efisiensi serta keterbatasan sumber daya, biaya, waktu, dan tenaga.

Kriteria dalam pemilihan Informan adalah : Kriteria inklusi : a. Kemampuan informan untuk berkomunikasi dan memberikan informasi yang diperlukan dalam penelitian ini ( tidak tuli, bisu, dan gagap). Pertimbangan ini menyangkut kualitas jawaban. b. Bersedia menjadi informan c. Tidak mengalami demensia, amnesia d. Tidak mengalami Gangguan Jiwa ( Isolasi sosial, PK, Harga diri rendah, dll) e. Sudah tinggal di panti $>6$ bulan . Kriteria ekslusi adalah lansia yang tidak mampu berkomunikasi dengan baik dan lancar ( Gagap, Tuli, dan Bisu).

Metode pengumpulan data. yang digunakan dalam pengumpulan data adalah 1. wawancara mendalam (indepth interview), Teknik wawancara mendalam (indepth interview) yang digunakan adalah wawancara semi terstruktur. Untuk mempermudah melakukan wawancara yang akan nantinya di rekam melalui alat perekam voice recorder dengan didahului oleh persetujuan oleh informan. 2. Observasi yang dilakukan adalah observasi pastisipasi pasif (pasif participative) dimana 
peneliti mengamati objek penelitian tanpa terlibat langsung dalam lingkungan yang diteliti. 3. Pengumpulan data untuk latar belakang sosio demografi lansia digunakan metode studi dokumentasi dan wawancara bila dalam dokumen tidak ditemukan data. Pada studi kualitatif, interpretasi dan analisis data terjadi secara stimultan, Peneliti mengkategorikannya, mengembangkan analisa tematik dan menyatukan tema.

\section{HASIL DAN PEMBAHASAN}

Pada Interaksi Sosial Sesama Lansia dan Pengasuh yaitu : 1. Kerjasama kebersihan wisma dan menolong teman yang sakit. Lima orang informan mengatakan bahwa kerjasama dan koordinasi sesama lansia dalam menjaga kebersihan wisma terjalin baik, terutama bagi lansia yang masih sehat, kuat, dan masih waras. Tidak ada masalah dalam hal kerjasama, bagi lansia yang sakit tidak perlu bekerja dan tidak dipaksakan. Namun ditemukan pula lansia yang pemalas dan tidak acuh dengan kebersihan wisma. Kalaupun dibuat daftar piket pembagian tugas tidak dilaksanakan percuma saja.

Para lansia yang masih sehat, kuat, dan waras inilah yang lebih banyak berperan dalam membersihkan wisma dan pekarangan. Namun seperti terungkap bahwa salah satu penyebab terjadinya konflik antara sesama lansia di panti adalah karena masalah kebersihan kamar, wisma, dan pekarangan. Timbul kecemburuan sosial dan kebosanan di antara sesama lansia dalam kebersihan wisma karena merekalah yang selalu bekerja.

Hal ini melahirkan kebijakan pimpinan panti bahwa pengasuhlah yang bertugas dan bertanggung jawab dalam membersihkan wisma, pekarangan wisma merupakan tugas dan tanggung jawab tukang kebun. Kebersihan wisma tidak lagi menjadi permasalahan, namun pada beberapa wisma kebersihan dikerjakan bersama antara lansia dan pengasuh, dikerjakan bergantian sesuai dengan kemampuan masing-masing, sehingga wisma bersih, rapi, dan di pekarangan ditanam bunga-bungaan. Satu orang informan mengatakan bahwa hanya pengasuhlah yang bertugas membersihkan wisma, karena di wisma mereka semua lansia sudah sakit-sakitan. Pengasuh membangkitkan semangat dan kreasi lansia dalam memecahkan dan mengurangi rasa putus asa, rasa rendah diri, rasa keterbatasan yang dimiliki lansia (Depsos, 2007).

Bahkan ada yang membantu membersihkan dahak yang berceceran, walaupun jijik, tetap ditolongnya, seperti diungkapkan oleh informan 5: "Ya ... kalau ada kawan yang sakit saya bantu merawatnya, memberi makan, menyuapkannya, meminumkan obatnya. Bahkan kalau dia batuk, dahaknya sering berceceran, saya bantu melapnya ... saya bantu membersihkannya. Walaupun saya jijik ... tapi saya tetap menolongnya ". Menurut Depsos (2007) di panti perlu ditumbuhkembangkan rasa kebersamaan, sehingga para lansia tidak menjadikan dirinya sebagai individu yang terisolasi. Dengan demikian mereka saling bersahabat, saling bersosialisasi, dan merasa memiliki identitas, serta memperoleh rasa aman dan tentram. 2. Upaya lansia menjalin komunikasi sesama teman : Empat orang informan mengatakan bahwa komunikasi yang terjadi antara sesama lansia antara lain sering bercerita, bersenda gurau, dan dijadikan tempat bercerita (curhat) oleh sesama teman di panti . Bercerita tentang teman yang suka bergunjing, pemalas, sombong, dan cerita tentang masa mudanya dulu, seperti diungkapkan informan $1:$ : $Y a$ ... kalau bercerita saya senang, macammacamlah ... tentang pengalaman hidup, tentang kehidupan masa muda dulu. Saya sebagai tempat curhat bagi teman-teman di sini, berbagai macamlah ceritanya dan saling bertanya “. Pendekatan komunikasi tidak kalah pentingnya dengan upaya pengobatan medis dalam proses penyembuhan atau ketenangan lansia (Nugroho,2010).

Komunikasi lain yang terjadi sesama lansia di panti terlihat dalam berkunjung ke 
wisma teman. Tiga orang informan mengatakan bahwa mengunjungi wisma lain apabila ada keperluan saja. Hanya sekalikali berkunjung ke wisma kawan dan itu pun bermain ke wisma tertentu saja, karena banyak teman yang tidak seide dan sepaham, Dua orang informan mengatakan bahwa mereka tidak ada berkunjung ke wisma lain karena sudah semua wisma pernah ditempatinya dan sebagian besar penghuni wisma wanita kenal dengannya, di samping keterbatasan fisik dan tidak kuat lagi, seperti diungkapkan oleh informan 6: "Semua wisma di sini sudah pernah saya tempati, sudah tidak asing lagi bagi saya. Jadi ... saya tidak pernah lagi bermain dan berkunjung ke sana ". Hanya satu orang informan yang mengatakan bahwa dia sering berkunjung ke wisma lain, seperti dikatakan informan 4 :" Ya ... sering juga saya datang menemui kawan di wisma lain, bersilaturrahmi dan bercerita. Kalaupun tidak pergi ke tempat kawan, di jalan pun sering bertemu, dan kegiatan-kegiatan lain “.

Pengasuh harus mampu menciptakan hubungan sosial antara sesama lansia dan dengan petugas (pengasuh). Memberikan kesempatan yang seluas-luasnya kepada lansia untuk mengadakan komunikasi, dan rekreasi, seperti jalan pagi, senam bersama dan hiburan-hiburan lain (Nugroho, 2010).

Bila mengalami masalah dua orang informan mengatakan memilih untuk menceritakan kepada teman dekat yang dapat dipercaya , kemudian baru kepada pengasuh, seperti yang diungkapakan informan 2 : "Bila mengalami masalah atau kesulitan saya bercerita dan berkonsultasi dengan teman dekat, teman yang seide dengan saya, ya ... teman sekamar. Kalau masalah yang berhubungan dengan wisma, saya konsultasikan dengan pengasuh ". Satu orang informan mengatakan bahwa apabila mengalami masalah diceritakan kepada pengasuh terlebih dahulu, kemudian baru disampaikan ke pihak kantor (pengurus), tidak menceritakan kepada teman. Salah satu peran dan fungsi pengasuh adalah memberikan pelayanan bimbingan dan konseling terhadap permasalahan yang mereka alami (Nugroho,2010). 3. Konflik sesama Lansia dan Penyebabnya : Satu orang informan mengatakan bahwa konflik yang terjadi antara sesama lansia di panti disebabkan oleh sikap dan perilaku teman yang tidak beretika, egois, pelit, dan sombong. Seperti diungkapkan oleh informan 3 :" Pernah tidak bertegur sapa dengan kawan kawan-kawan disini. Bapak EK itu orangnya egois, manden sajo inyo disiko. Saya sudah lelah membersihkan halaman belakang diletakkannya nasi rantang di situ. Saya nasehatkan, dia menantang pula, saya emosi ... saya ajak dia keluar ... berlari dia masuk kamar. Saya pukul meja ... dia terkejut. Dia juga suka memasak air dan menggosok pakaian malam hari sehingga lampu mati karena amperenya berbalik".

Untuk meminimalkan dan mengatasi permasalahan ini peran pengasuh sangat diharapkan, karena sesuai dengan tugas dan tanggung jawabnya untuk menciptakan suasana yang kondusif di kalangan lansia di panti. Bimbingan sosial dan konseling di sini sangat diperlukan agar hubungan sesama lansia berjalan baik dan harmonis. Mereka harus dapat menghilangkan perasaan egonya, perasaan bahwa dirinya lebih baik, menghilangkan sifat cemburu, dan saling mencurigai. Mengikuti berbagai kegiatan-kegiatan bersama di panti bertujuan untuk mempererat interaksi dan menjalin kebersamaan di antara mereka (Santosa, 2009). 4. Jenis Pelayanan yang diberikan Pengasuh : Pelayanan yang diberikan oleh pengasuh kepada lansia di panti sangat bervariasi. Empat orang informan mengatakan bahwa pelayanan yang diberikan oleh pengasuh adalah merawat lansia yang sakit. Seperti diungkapkan oleh informan 2 :" Kalau ada teman yang sakit pengasuh yang memintakan obat kepada Bu Rani. Bila dalam keadaan darurat di bawa ke Puskesmas dengan mobil pribadi pengasuh". Terkadang tengah malam pun pengasuh dibangunkan karena ada lansia 
yang sakit. Pengasuh adalah orang yang paling dekat dengan lansia dan salah satu jenis pelayanan yang diberikan oleh pengasuh adalah pemeliharaan kesehatan, kebersihan, dan merawat pada saat menderita sakit ( Depsos, 2007).

Dua orang informan mengatakan bahwa pengasuh memberikan bimbingan dan konseling terhadap lansia. Kalau ada masalah sesama lansia di panti diberitahukan kepada pengasuh, pengasuhlah yang menasehati, membimbing, dan menyelesaikannya. Pemberian bimbingan rohani, berupa bimbingan mental, keagamaan, dan kemasyarakatan diberikan oleh pengasuh, petugas panti, dan instansi terkait ( Depsos, 2007). Proses bimbingan pertama kali diberikan untuk menentramkan perasaan lansia. Lansia merasa bimbang karena situasi di panti berbeda dengan saat berada di tengah keluarga. Mereka harus beradaptasi dengan lingkungan yang baru ( Nugroho, 2010).

Satu orang informan mengatakan bahwa jenis pelayanan lain yang diberikan pengasuh adalah mendorong lansia untuk mengikuti setiap kegiatan yang diadakan di panti. Kegiatan-kegiatan yang diprogramkan di panti seperti senam, keterampilan, kesenian, wirid, bimbingan sosial, dan goro bersama. Setiap kegiatan ini harus diikuti oleh semua lansia penghuni panti, kecuali bagi lansia yang sakit (PSTW Sabai Nan Aluih, 2011). 5. Sikap dan Perilaku Pengasuh dalam Interaksi : dalam memberikan pelayanan kepada lansia muncul dua reaksi, yaitu reaksi yang menyenangkan (reaksi positif) dan reaksi yang tidak menyenangkan (reaksi negative) : a. Tindakan / cara kerja pengasuh yang menyenangkan : Dua orang informan mengatakan bahwa tindakan atau cara kerja pengasuh yang menyenangkan adalah kerjasama, komunikasi dengan pengasuh terjalin baik, dan saling menghargai. Diskusi, dan bertukar pikiran, serta bercerita merupakan salah satu upaya pengasuh dalam pendekatan sosial. Memberi kesempatan untuk berkumpul bersama kepada lansia berarti menciptakan sosialisasi diantara mereka. Pendekatan sosial merupakan suatu pegangan bagi pengasuh bahwa orang yang dihadapi adalah makhluk sosial yang membutuhkan orang lain (Suparyanto,2011).

Dua orang informan mengatakan bahwa merawat lansia yang sakit adalah tindakan atau cara kerja pengasuh yang menyenangkan. Seperti diungkapkan oleh informan 5 :" Pengasuh perhatian merawat kami yang sakit, memberi obat, malammalam pun kami bangunkan bila ada lansia yang sakit". Pada umumnya lansia di panti sudah berusia rata-rata diatas 70 tahun, usia yang demikian memerlukan perhatian yang lebih intensif, apalagi ketika mengalami sakit. Pengasuh merupakan petugas yang selalu berinteraksi dengan lansia baik siang maupun malam. Pengasuh harus mendekatkan diri dengan lansia, merawat dengan sabar, dan ramah menanyakan masalah, dan keluhan yang dirasakan. Sentuhan seperti genggaman tangan sangat berarti buat mereka ( Nugroho, 2010).

Dua orang informan lagi mengatakan bahwa kepedulian terhadap kebersihan dan keindahan wisma, serta disiplin dan cepat tanggap adalah tindakan atau cara kerja pengasuh yang disenangi lansia di panti. Menurut Green dalam Notoatmodjo (2010) sikap dan perilaku petugas kesehatan, tokoh agama dan tokoh masyarakat merupakan faktor penguat atau faktor pendorong terbentuknya perilaku. Perilaku petugas kesehatan atau petugas lain yang baik dan positif seperti pengasuh, akan mendorong lansia berperilaku baik dan positif pula, sehingga lansia senang dan betah tinggal di panti. b. Tindakan / cara kerja pengasuh yang kurang menyenangkan. Dua orang informan mengatakan bahwa pengasuh kurang luwes dan kaku dalam memberikan pelayanan, kurang berkomunikasi dan menanggapi saran, kurang menghargai serta terkadang suka marah karena rumah kotor dan tidak bersih. Seperti diungkapkan oleh informan 3:“ Kadang-kadang pengasuh agak kaku pula memberi pelayanan. Ada usulan kita 
dicuekin. Dulu waktu ada kematian, saya usulkan untuk mengeluarkan kursi dari aula agak 15 buah. Kan rancak dilihat orang, Nampak persatuan kita di sini. Tidak bias katanya, duduk saja di dalam”.

Pelayanan pengasuh yang kaku berdasarkan observasi peneliti bisa disebabkan karena pengasuh yang berkeluarga tinggal bersama lansia dalam satu wisma. Pengasuh disini tinggal bersama anak-anaknya, jadi selain pengasuh mengurus kepentingan keluarganya , mereka juga memberikan pelayanan kepada lansia dalam berbagai hal. Pengasuh lebih banyak terfokus untuk mengurus kepentingan keluarganya, dibandingkan dengan kepentingan lansia. Pelayanan kepada lansia dilakukan memang sebatas tugas dari mereka saja. Pengasuh jarang terlihat berkomunikasi bahkan bersenda gurau dengan lansia di wisma. Sebenarnya perbedaan pengasuh yang berkeluarga dengan yang tidak berkeluarga (individu) yang tinggal bersama lansia dalam satu wisma mempunyai keuntungan tersendiri. Pengasuh yang berkeluarga terdiri dari 2 individu dewasa, dimana apabila pengasuh laki-laki tidak bisa dalam memberikan pelayanan kepada lansia, istri nya bisa membantu memberikan pelayanan misalnya : menyapu rumah, mengepel, dan lain-lain.

Pengasuh harus memberikan perhatian dan mengadakan kontak sesering mungkin, baik verbal maupun nonverbal. Duduklah bersama mereka sekurangkurangnya sekali sehari, ikutsertakan lansia dalam mengambil beberapa keputusan. Pendekatan ini menyenangkan dan menarik bagi lansia karena dia merasa diperhatikan (Nugroho,2010).

\section{KESIMPULAN DAN SARAN}

Dari 5 variabel penelitian yaitu : kerjasama, komunikasi, konflik, jenis pelayanan yang diberikan oleh pengasuh serta tindakan atau cara kerja pengasuh di dapatkan 5 tema yaitu :1. Kerjasama menjaga kebersihan wisma dan menolong teman yang sakit. Ada koordinasi dan kerjasama yang baik antara sesama lansia dan pengasuh dalam membersihkan wisma, terutama bagi yang sehat, sedangkan bagi lansia yang sakit tidak dipaksakan, namun ditemukan pula lansia yang kurang peduli. Kerjasama menolong dan merawat teman yang sakit terjalin dengan baik, lansia saling membantu terutama dalam hal memberikan obat, membantu makan dan minumnya, mengambil nasi dan air minum ke dapur, mencuci pakaian dan peralatan makannya (piring, rantang, gelas, sendok). 2. Upaya Lansia menjalin Komunikasi sesama teman. Lansia senang bercerita dan bersenda gurau sesamanya, bercerita tentang masa lalunya, bahkan ada lansia sebagai tempat curhat bagi temannya. Pilihan teman sebagai tempat cerita dan curhat adalah teman akrab dan dianggap cocok. Ada juga lansia yang tidak suka bercerita dan lebih senang mendengar , sedangkan hambatan komunikasi adalah ketidakcocokan dengan teman dan tidak nyambung karena faktor fisik dan kepikunan. Para lansia berkunjung ke wisma lain apabila ada keperluan saja, dan hanya mengunjungi wisma teman akrab dan teman-teman yang sepaham dengan mereka. Ada lansia yang tidak pernah mengunjungi teman karena keterbatasan fisik dan sakit yang dialami. Bila ada masalah dan kesulitan lansia berkonsultasi dan bercerita kepada teman dekat, kemudian kepada pengasuh, dan kemudian ke kantor serta ada yang memendam sendiri, memikirkan sendiri, dan hanya mendekatkan diri kepada Allah. 3. Konflik sesama Lansia dan penyebabnya. Konflik sesama lansia terjadi karena kecemburuan karena merasa pacarnya diambil teman, masalah kebersihan, ketidakpedulian teman dalam kebersihan wisma, tidak disiplin dan tidak mau mengikuti peraturan yang ditetapkan oleh pengasuh dan panti. Konflik lain terjadi karena perilaku teman yang kurang beretika, sombong, egois, pelit, dan tidak mau bergaul. 4. Jenis Pelayanan yang diberikan Pengasuh. Memberikan bimbingan dan konseling kepada lansia yang bermasalah dan mengalami konflik, mendorong lansia berperan serta dalam berbagai kegiatan di panti (senam, wirid 
agama, kesenian, bimbingan sosial, pembinaan bakat, dan keterampilan). Membantu kebersihan dan keindahan wisma, mengurus kelengkapan fasilitas wisma, dan merawat lansia yang sakit. 5 . Sikap dan Perilaku Pengasuh dalam Interaksi. Tindakan atau cara kerja pengasuh yang menyenangkan bagi lansia adalah perhatian dalam merawat lansia yang sakit, kerjasama, komunikasi dengan lansia terjalin baik, dan saling menghargai, serta kepedulian pengasuh terhadap kebersihan dan keindahan wisma, disiplin dan cepat tanggap merespon permasalahan lansia di panti.Tindakan atau cara kerja yang kurang menyenangkan adalah tindakan pengasuh yang sering memindahkan lansia dari satu wisma ke wisma lain, pengasuh kaku dalam memberikan pelayanan (kurang memperhatikan saran), pemarah, kurang berkomunikasi, dan sering menyuruh suatu pekerjaan kepada lansia tertentu saja.

Saran kepada Pengasuhdiharapkan lebih proaktif dalam memberikan bimbingan sosial dan membina hubungan sesama lansia di panti. Karena lemahnya interaksi sesama lansia dan berbagai konflik yang terjadi, merupakan indikasi bahwa peran pengasuh belum terlaksana secara optimal, Pengasuh diharapkan berpartisipasi dalam kegiatankegiatan lansia di panti, seperti keikutsertaannya dalam bimbingan keagamaan, bimbingan keterampilan, dan bimbingan sosial serta acara kesenian dan hiburan atau kegiatan-kegiatan lainnya. Dalam memberikan pengasuhan dan pelayanan diharapkan pengasuh lebih luwes, tidak kaku, saling menghormati, menghargai, merespon berbagai saran dan dapat berkomunikasi atau bersosialisasi dengan baik, serta berupaya semaksimal mungkin membina lansia yang diasuhnya. Dengan demikian keluhan lansia yang sering diungkapkan lansia dapat diatasi.

Kepada Pimpinan Panti, Untuk dapat mengadakan pelatihan tentang pekerja sosial lanjut usia. Hal ini perlu dilakukan karena mayoritas para pengasuh berlatar belakang pendidikan umum.Untuk dapat menyediakan atau mengadakan peralatan- peralatan yang diperlukan dalam bimbingan keterampilan, sehingga pelaksanaan bimbingan keterampilan dapat terlaksana secara terus menerus dan tidak terputusputus. Dengan bimbingan keterampilan ini para lansia merasa bahwa dirinya masih mampu berkarya. Untuk meningkatkan kualitas pelayanan, disarankan pimpinan beserta pengasuh untuk melakukan kunjungan atau studi banding ke PSTW atau panti sosial lainnya. Dengan demikian saling bertukar informasi, pengalaman/ pengetahuan dalam pengelolaan panti dan pemberian pelayanan kesejahteraan sosial pada lansia.

Kepada Peneliti Lain, disarankan untuk mengadakan penelitian secara kuantitatif untuk mengetahui hubungan interaksi sosial sesama lansia, dengan pengasuh dan keluarga dengan kepuasan lansia di panti, terutama tentang 5 variabel atau tema yang sudah teridentifikasi.

\section{DAFTAR PUSTAKA}

Badan Pusat Statistik. (2007). Penduduk lanjut usia. di akses tanggal 24 Oktober

2011 dari www. Menegpp.go.id/ aplikasidata/index.php?option=com Badan

Pusat Statistik, Susenas. (2007). Penduduk lanjut usia. diakses tanggal 24

Oktober 2011 dari www.Menegpp.go.id/aplikasidata/index. php?option=com

Creswell, J.W. (2002). Research design: qualitative and quantitative approach.

California : Sage Publication

Departemen Sosial RI. (2007). Pelembagaan lanjut usia dalam kehidupan bangsa.

Jakarta.

Departemen Sosial RI. (2007). Pola pembinaan lansia di panti werdha. Jakarta

Departemen Sosial RI. (2011). Data Penduduk Sasaran Program Pembangunan

Kesehatan. Jakarta : Pusat Data dan Informasi 
Devito , J. (2005). Komunikasi antar manusia. Jakarta : Professional book

Gumay, A. (2011). Komunikasi antar pribadi antara penghuni dan pengasuh di

panti jompo. di akses tanggal 29 September 2011 dari http://andrewsbgumay.blogspot.com/201 1/03/komunikasi-antar-pribadiantara.html

Hardywinoto \& Setiabudi, T. (2005). Panduan gerontologi dari berbagai aspek.

Jakarta : Gramedia Pustaka Utama

Hurlock, E. (2003). Psikologi perkembangan suatu pendekatan sepanjang

rentang kehidupan: Jakarta : Erlangga

Notoatmodjo, Soekidjo. (2010). Pendidikan dan Perilaku Kesehatan. Jakarta :

Rineka Cipta

Nugroho,W. (2010). Perawatan usia lanjut. Jakarta : EGC

Santosa, S. (2009). Dinamika kelompok. Jakarta : Bumi Aksara

Speziale, H.S \& Carpenter, D.R (2007). Qualitative research in nursing : advancing

the humanistic imperative. Philadelphia : Lippincott Williams \& Wilkins a wolters Kluwer business.

Suparyanto. (2011). Konsep Lanjut Usia. Diakses tanggal 4 Oktober 2011 dari http://fiinsayblog.blogspot.com 